\title{
Environmental Justice as Scalar Parity: Lessons From Nuclear Waste Management
}

\section{Matthew Cotton ${ }^{1}$}

Published online: 18 July 2018

(C) The Author(s) 2018

\begin{abstract}
The development of major infrastructure projects, such as power stations, waste facilities or transport networks, commonly raises concerns of how to ensure environmental justice within policy and planning. Environmental justice has been divergently theorised, though procedural/participative, distributive and recognitionrelated elements are commonly cited. With growing inter-disciplinarity between normative ethics and the geographic social sciences, there is a renewed interest in the scalar aspects of environmental justice (particularly in relation to infrastructure projects) - how the framing of environmental decisions at multiple and conflicting scales results in disparities between locally affected communities, and regional and national decision-making authorities. In analysing this problem, the paper has three principal aims. The first is to outline the problem of scalar environmental justice. The second is to explore a practical case of scalar environmental justice, by examining the decision-making processes surrounding radioactive waste management in the UK. The third is to outline a new concept of "scalar parity" derived from the radioactive waste policy process, whereby local communities and regional and national political stakeholders are charged with balancing their competing interests through the "fulcrum" of a partnership organisation, to fairly resolve environmental justice disputes. This scalar parity model is used as an exemplar of good practice in environmental justice resolution that could be applied to other major infrastructure projects.
\end{abstract}

Keywords Environmental justice · Nuclear waste management · Scalar parity · Politics of scale

Matthew Cotton

matthew.cotton@york.ac.uk

1 Department of Environment, University of York, Wentworth Way, Heslington, York YO10 5DD, UK 


\section{Introduction}

The construction of large-scale infrastructure projects is a major component of economic development planning globally, one that is of increasing political significance. In Europe, concerns over mitigating anthropogenic climate change necessitate the rapid development of low-carbon energy and transport infrastructure. This, in turn, has stimulated member states to initiate planning policy reforms to "streamline" (and hence speed up) decision-making processes for such infrastructures. In the context of highly liberalised infrastructure markets, infrastructure planning has become largely depoliticised: processes for siting wind farms, nuclear power stations, waste facilities, ports and roads are moving away from political influence and bureaucratic delay. Yet as Newman (2009) argues, this potentially undermines the sustainable development goals these infrastructures were intended to address, and increases the political and ethical controversies that surround some major projects.

In this paper, I explore the policy and planning of major infrastructure through the lens of environmental justice. Firstly, I outline the existing literature on environmental justice, specifically examining the scalar relationships of justice and injustice implicit within infrastructure development. Secondly, I examine a critical case of major infrastructure-related environmental justice, namely that of long-term radioactive waste management (RWM) in the UK. Through this case I, thirdly, develop and discuss the concept of scalar parity-what I describe as an "evaluative yardstick" (Webler, 1995) for assessing the relative success of environmental justice within major infrastructure plans and programmes.

\section{Environmental Justice}

The concept of environmental justice is well established in relation to both grassroots political activism and academic analysis of environmental rights, the fair distribution of health and environmental risks weighed against socio-economic benefits, the expansion of democratic norms of participation and advocacy, and the protection of community voice, political, social and place identities stretching from local communities to global ecological and climate systems (Agyeman, 2002; Bullard, 2000; Ciplet, Roberts, \& Khan, 2013; Faber \& McCarthy, 2001; Hofrichter, 1993; Houston, 2013; Schlosberg, 1999; Syme \& Nancarrow, 2001; Walker, 2009; Walker $\&$ Bulkeley, 2006). From a justice standpoint, historically, polluting and otherwise unwanted facilities have been sited through processes commonly dominated by race, class and income inequality that act as proxy distributors of environmental quality (Agyeman, 2002; Low \& Gleeson, 1998). The siting of waste disposal sites, chemical works, intensive agriculture and resource extraction operations has, particularly in the USA, had disproportionately adverse environmental impacts on communities inhabited by African-American, Hispanic, Native American and Asian-American populations, migrant farm workers and the working poor (Bullard, 1989, 1993; Cole \& Foster, 2001; Cutter, 1995; Foster, 1993). 
Environmental justice had its roots in the civil rights movement-where environmental quality both mirrors and reinforces broader racial disparities, marginalisation and injustice. High-profile cases such as Love Canal (Levine, 1982) and Warren County (Bullard, 1989) elevated "anti-toxics" environmental justice movements in the USA's wider political discourse. However, in Europe the grassroots activism of race-related environmental justice movements had little direct equivalence, and so needed to be re-contextualised (Dobson, 1998). The (re)contextualisation of environmental justice is important, because justice is an important frame through which environmental problems and crises are imagined (Clayton, Koehn, \& Grover, 2013), and what is perceived as environmentally just is, in turn, influenced by external contextual factors (Parris et al., 2014). In the UK (and the broader European context), the concept of sustainable development has been a dominant lens through which issues of environmental justice can be resolved. In the UK, for example, environmental justice scholarship has become associated with the concept of "just sustainabilities"-which links environmental quality, sustainable development outcomes and processes of social inclusion (Agyeman, 2003; Agyeman \& Evans, 2004). Thus, in the UK, empirical research into environmental justice has focused upon communities affected by social deprivation and/or economic and political peripheralisation as a result of pollution, infrastructure plans and projects, waste flows and resource extraction (for example, Agyeman \& Evans, 2004; Bickerstaff \& Agyeman, 2009; Blowers, 2010; Cotton, 2014; Groves, 2015; Walker et al., 2005; Watson \& Bulkeley, 2005).

When it comes to energy-related developments specifically, environmental justice has been recently reframed as energy justice: expanding this ethical/political analysis to issues of security of energy supply, the impacts of fuel extraction activities, reducing reliance on non-renewable fuel consumption (including fossil fuels and nuclear fission), changes to geopolitical relationships stemming from resource extraction, energy transportation and distribution, issues of energy service access, fuel affordability and poverty, and the implications of energy system development for carbon dioxide emissions reduction in the face of anthropogenic climate change (Hall, 2013; Jenkins, McCauley, \& Warren, 2017; McCauley et al., 2013; Sovacool $\&$ Dworkin, 2015). Energy justice is of relevance to various facets of energy policy including subsidies and taxes (renewable obligations, feed-in-tariffs), fuel pricing (e.g. fuel poverty) and consumption indicators (e.g. smart meters) (McCauley et al., 2013).

Where environmental justice and energy justice overlap is where issues around site selection and development occur. A variety of energy infrastructure-related topics have come under academic scrutiny including coal (Hernández, 2015) and shale gas extraction (Cotton, 2017a), nuclear power (Blowers \& Pepper, 1988; Whitton et al., 2015), onshore wind (Bell et al., 2013; Simcock, 2014), energy from waste facilities (Cotton, 2014), biomass (Upreti \& van der Horst, 2004), gas pipelines (Groves, 2015) and electricity transmission lines (Cotton \& DevineWright, 2013; Knudsen et al., 2015). Despite the different contexts and cases, whether it is through unequal class and race relations or other forms of socio-economic/political inequality, ensuring justice for communities is commonly understood to involve three dimensions-distributive justice (concerning the processes 
of risk and benefit distribution); procedural/participative justice (concerning the conditions under which decisions over distributional outcomes are made and by whom); and recognition justice whereby mutual respect for the equal dignity of autonomous beings is the principal concern (Schlosberg, 2003; Walker, 2009).

\section{Political Equality as Environmental Justice}

The broad categories of distributive, procedural and recognition justice have been divergently theorised (see, for example, Agyeman, 2002; Kaswan, 2002; Lawrence, Daniels, \& Stankey, 1997), but of principal concern here, is the inter-relationship between the three elements. This is addressed by Shrader-Frechette (2002) directly through The Principle of Prima Facie Political Equality (hereafter PPFPE). ShraderFrechette notes that threats to informed consent commonly underlie violations of environmental justice. In the PPFPE, political equality, whereby all citizens are given equal consideration and concern with respect to decisions over distributive outcomes, is the only defensible position when it comes to the imposition of environmental harm upon affected communities. The onus for justifying environmental risks rests with those proposing potentially environmentally damaging developments, not those opposing them, and imbalances in benefit/risk distribution should be rectified through distributive means (such as through a combination of in-kind benefits, compensation payments and increased employment opportunities). Achieving fair distributive outcomes is dependent upon a participative inclusion whereby all those affected within a community are respected and given equal opportunity for consideration in decision-making. Heterogeneous stakeholders including affected site communities should be given autonomous rights to free and informed consent in a manner equivalent to patients of medical procedures, i.e. in a way that offers transparent consideration of available information and is free from coercion. (All of the above are summarised from Shrader-Frechette, 2002, 24-29, 77.)

From Shrader-Frechette's work I conclude that environmental justice is achieved only when polluting organisations successfully justify the imposition of additional environmental risks and burdens upon a community and then rectify the imbalances produced to local communities as a means to rebalance the injustice imposed when a developer or polluter disrupts environmental quality in the pursuit of profit or other private benefit. Attention must be paid, therefore (as Senecah, 2004 notes, in parallel to Shrader-Frechette's PPFPE), to the political powers of community actors in decision-making processes: namely through access to decision-making through open dialogue and utilisation of available information through informed and active capacity for consent, community standing through recognition and esteem for local voices without coercing or marginalising minority voices (i.e. recognition-related justice Schlosberg, 2007), and influence through opportunities for community control in the decision-making process. These concepts of political equality are key criteria in the normative evaluation of justice in relation to the analysis of siting procedures and broader political decision-making processes over energy transitions. 


\section{The Scalar Nature of Environmental Justice}

The works of Shrader-Frechette and Senecah highlight the importance of political equality and community voice to normatively evaluate the underlying politics of benefit and risk distributions and the relative capacities of marginalised communities to have meaningful environmental justice. However, recent environmental justice scholarship (and by extension energy justice scholarship) has advanced these concepts by focusing specifically upon the geographic nature of justice-evaluating how communities can become disadvantaged in local hazardous site development through institutionalised processes of disempowerment enacted through spatial and scalar relations (Jessup, 2014). Towers (2000), in particular, asserts that environmental justice is fundamentally defined by scale: for example, between local scales of community protest and broader spatial and governance scales at which the discourses of environmental justice are directed, such as to national environmental programmes.

Kurtz (2003) notes that within the body of environmental justice scholarship there are two main ways in which spatial and scalar relations are conceptualised. The first is through measuring distribution patterns of environmental hazards and benefits within and between different demographic groups. The second is to understand the broader socio-political processes that foster environmental disparities in order to link local conditions of pollution to practices operating at broader spatial scales. For example, we might link the politics of regional or national energy system development with the impacts of local fuel resource extraction or power generation technology siting practices. Kurtz concludes, however, that although geographic and governance scales are implicit within these research agendas, scale itself, and its role in shaping responses to environmental justice, is not overtly problematised, and it is this element that my analysis addresses.

Theorising scale in environmental justice scholarship follows a broader turn within geographic inquiry to understanding scale as concept through which environmental controversies are framed by different actors (see Bickerstaff \& Agyeman, 2009; Kurtz, 2008). Scale is understood to be socially constructed and performed, rather than something which is physically defined, static and immutable (Jonas, 2006; Marston, 2000). Scale is important to negotiating environmental justice disputes because the institutions that site hazardous/locally unwanted land uses typically specify scales - notably, national, regional and local scales, and then devise regimes for the assessment of projects in each category (Jessup, 2014). Scalar justice therefore involves facilitating dialogue between actors within and across multiple scales simultaneously.

To explore this issue of scalar justice I draw lessons from the processes involved in managing radioactive wastes in the UK. In the following discussion I give a brief overview of the case and then use it to define the tenets of a scalar parity concept, which becomes an evaluative mechanism for assessing environmental justice within this (and other) infrastructure plans and projects. 


\section{The Radioactive Waste Challenge}

In the UK, radioactive waste management (hereafter RWM) has long been treated by policy makers as a technical and industrial process, and so the expertise of "hard" scientific and engineering professionals was prioritised until the late 1990s (Blowers \& Sundqvist, 2010; Malone, 1991). A lack of safe long-term waste management in the early 1950s and 1960s left a legacy of radiotoxic materials stored in ponds, silos and tanks that have long passed their design life, presenting a significant technical challenge and persistent environmental hazard (Hastings et al., 2007). Nuclear fuel reprocessing and weapons-related activities have also created a vast stockpile of plutonium, raising concerns about terrorism, theft and proliferation (Kershaw et al., 2001). Nuclear industry processes produce spent fuel and associated fission products (heat-generating high-level waste-HLW), alongside contaminated materials (intermediate- and low-level wastes - ILW and LLW). The latter two categories of wastes continue to grow as the ageing reactor fleet is brought offline and decommissioned, and predicted new volumes of all waste classifications may emerge under new nuclear build scenarios.

The political history of the UK's legacy of radioactive waste from the industry's early inception is well researched (Blowers, 2010, 2016; Blowers, Lowry, \& Solomon, 1991; Cotton, 2017b; Hall, 1986; Kemp, 1992). Historical analysis of RWM policy shows a slow shift from little concern over safe long-term management practices in the 1950s and during the rapid expansion of the nuclear industry in the 1960s, to a shift towards environmental protection as an intergenerational justice issue highlighted in the Royal Commission on Environmental Pollution report in 1976 (Royal Commission on Environmental Pollution, 1976). In the 1980s there was a shift away from sea dumping of intermediate level wastes (Holliday, 2005) and governmental recognition for swift and independent siting processes. However, repeated political failures to site a deep geological disposal facility (an underground repository to house wastes until their radioactivity decays to safe levels) for HLW in the 1970s prompted the creation of an industry body the Nuclear Industry Radioactive Waste Executive (Nirex) in 1982 to manage the process. Nirex, however, was also unsuccessful through the 1980s and 1990s (Berkhout, 1991; Blowers \& Pepper, 1988; Kemp, 1992), culminating in the failure of the siting process for a Rock Characterisation Facility ( $\mathrm{RCF}$ - an underground laboratory to test the host rock for a repository) in 1997 (Kelling \& Knill, 1997), which left the UK without a longterm RWM strategy. The RCF failure was primarily due to ongoing concerns about the hydrological makeup of the site (McMillan et al., 2000) and other environmental impact factors, but issues of socio-political opposition were also significant. Nirex was accused of failing to allow sufficient opportunities for citizens to influence decision-making. Blowers $(2016,109)$, in particular, argues that this made Nirex appear as an arrogant and unsympathetic outsider. Durant (2007) goes further, suggesting that this was a means by which nuclear organisation sought to control publics. This subsequently contributed to broader undermining of public trust, not only in nuclear institutions such as Nirex, but more broadly in public trust of scientific and technical expertise. 


\section{Distributive Environmental Justice Concerns}

Radioactive waste management is a critical case study for environmental justice analysis. First, as a distributive injustice, the focus upon communities surrounding the Sellafield site (particularly Whitehaven) in the 1980s and 1990s revealed the underlying political and economic marginalisation of those communities. Whitehaven has remained dependent upon the nuclear industry (and its risk-bearing nature) across multiple generations. Nuclear-generated electricity benefits are widely dispersed across electricity grid-connected communities across the Northwest of England and beyond, but the risks are concentrated within a particular local setting (Blowers \& Pepper, 1988; Krütli et al., 2012). Siting processes for RWM that target existing nuclear communities potentially compound the distributive injustice by further adding environmental and public health risk factors.

Second, as a procedural injustice, Whitehaven and surrounding communities struggled to resist Nirex's largely technocratic (expert-led) authority or effectively engage with democratic mechanisms of community environmental protection, in part because of the legacy of secrecy that surrounds civilian nuclear engagements with communities (GreenPeace, 2005; Kyne \& Bolin, 2016); but also because the technological stigmatisation of Sellafield as a "dirty" place (the extension of this is that the people living there are themselves somehow "dirty" or "contaminated") (Castán Broto et al., 2010; Gregory \& Satterfield, 2002) has precluded other industries (such as coastal tourism) from becoming better established in the region. Thus, the threat of poverty from withdrawing nuclear industry activities from communities has a potentially coercive effect-the community surrounding Sellafield has been put in a position where it struggled to oppose an industry that sustains its local economy, despite the potentially negative health, and psycho-social effects it has had upon the residents (Blowers, 1999, 2016; Blowers, Lowry, \& Solomon, 1991; McSorley, 1990; Wynne, 1993). Despite the concentration of nuclear employment-related wealth, the Copeland District of Cumbria still falls within the $30 \%$ most deprived nationally for overall deprivation, within the $20 \%$ most deprived nationally in terms of employment deprivation and the $10 \%$ most deprived nationally in terms of health \& disability deprivation (Cumbria Intelligence Observatory, 2015). As the Managing Director of Copeland Borough Council states:

We are a community of two halves... we have got more PhDs per head of population in Copeland than anywhere else in the UK. We have the nuclearrelated wealth, which captures the highly skilled and the affluent and the upwardly mobile. But we also have those people who don't have the ability to access nuclear. (cited in Pidd, 2016).

\section{Changes in Procedural Justice in Radioactive Waste Management}

The failure of the RCF proposal in 1997 catalysed changes in policy direction towards more just outcomes for local communities, with increasing recognition 
that transparency, accountability and public acceptability of decision-making process were as important as technical feasibility and risk assessment accuracy (Atherton \& Poole, 2001). Though not explicitly couched in the language of environmental justice, the reframing of RWM policy under the former Labour Government that came into power in 1997, involved transformation in procedural, distributive and recognition-related elements implicitly. New Labour policy on RWM had an increased sensitivity towards social, political, ethical and psychological factors; and a turn towards participatory decision-making using processes of comprehensive multi-stakeholder engagement (Bergmans et al., 2015; Lawless, Whitton, \& Poppeliers, 2008) following a fundamental policy review (CoRWM, 2006a; Simmons \& Bickerstaff, 2006). This so-called participatory turn was reflective of broader transformation under Labour towards more collaborative forms of governance and the institutionalisation of public participation within the operation of Government departments and the achievement of sustainable development goals (Barnes, Newman, \& Sullivan, 2004; DETR, 1999).

The outcome of the policy review was the Managing Radioactive Waste Safely (MRWS) process that started in 2001. A new independent body, the Committee on Radioactive Waste Management (CoRWM), was later appointed in 2004. CoRWM oversaw a carte blanche review of radioactive waste management options (for details of the MRWS policy strategy, see DEFRA, 2001; Mackerron $\&$ Berkhout, 2009). Their assessment process combined multi-attribute decision analysis with independent ethical assessment (Blowers, 2006; Cotton, 2009), and a comprehensive public and stakeholder engagement (PSE) programme to work through the different technological strategies for waste management (CoRWM, 2011). The PSE programme comprised of a national stakeholder forum (with 5000 members), 8 CoRWM-selected discussion groups, 568 self-selecting discussion groups, 4 citizens' panels, a school project, open access web-based discussion guide, and stakeholder round-tables and public meetings at 14 nuclear sites (Collier, 2005; CoRWM, 2004, 2006b; Hunt, 2004)—with an ethos of "science on tap, but not on top" in contrast to Nirex's rather more technocratic approach (Mackerron, 2015; Nirex, 2005b).

CoRWM's final report to Government in 2006 concluded that safe interim storage and eventual deep geological disposal would be the preferred options, with repository site closure as soon as was practicable (CoRWM, 2006a). The outcome was essentially the same policy strategy as Nirex's from the 1980s (final deep geological disposal). However, by going through a fully "upstream" participatory technology assessment exercise this time around, without focusing upon specific sites (and hence targeting individual communities), the decision had greater democratic legitimacy and much stronger support from independent stakeholders and within Government (Cotton, 2017b). In essence, as Gregson (2012) argues, it created a "cold politics" of RWM. The MRWS process broke alleviated the procedural injustices of previous site-selection-based processes that assumed the technical superiority of geological disposal and then utilised public relations strategies to communicate decisions in one direction (from experts to "lay publics"- - sometimes referred to as Decide, Announce, Defend). The consequence was, in each case, that Nirex was forced to defend each proposal in public discourse, whilst simultaneously trying to 
alleviate emergent social and political opposition (what Gregson terms "hot politics"), whilst CoRWM's seeming political consensus and greater democratic legitimacy in Gregson's (bid.) terminology "cooled" the politics of RWM site selection such that a policy decision could be made.

\section{The Challenge of Implementing Radioactive Waste Management}

Government eventually accepted CoRWM's recommendations and then moved to progress the implementation of deep geological disposal. CoRWM released a document detailing the underlying concepts for implementing (siting) a geological repository (CoRWM, 2007) which emphasised volunteerism/voluntarism) such that communities move through a sequential decision-making process based upon full community participation and, if ultimately they decide to host a repository, they receive a community benefits package in return. Communities were first invited by Government to express a willingness to participate in an exploratory process for finding a site (the expression of interest EOI stage). This is the voluntarist aspect: there was no direct coercion from nuclear industry authorities or central government to push specific local authorities to step forward. Volunteer communities then became subject to a desk-based evaluation of geological knowledge of the region to rule out areas that would not be suitable for a repository. If deemed suitable, the community then, following an extensive public consultation process, would internally make the decision to participate (DTP). This meant further desk-based evaluation of suitable areas within the region, followed by surface and then underground investigations. At each stage, communities were given the option to withdraw from the process up to a predefined point (this was likely to be well before physical site development began) (ibid.).

The post-2006 implementation process showed similarities to previous siting processes - the technology under consideration remained as deep geological disposal and, in practice, the community was the same (Sellafield was the only volunteer for the EOI stage). What differed was the incorporation of distributive, procedural and recognition aspects more thoroughly within the decision-making process; providing institutional rebalancing to the aforementioned elements of environmental injustice seen in the 1970s, 1980s and 1990s. Specifically as a distributive justice issue, there are two elements. The first concerns the legacy waste issue-one that dominates the overall RWM problem. At Sellafield the safe onsite storage of wastes is a top priority, within the MRWS process, this received greater recognition-that the current and shorter-term environmental safety of residents in Whitehaven and the other population centres surrounding Sellafield were of greater importance. Efforts have thus been made to reduce risks to existing storage sites (based on a principle of reduction to as low as reasonably practical-ALARP), not just focus on the disposal of wastes underground. Secondly, by adopting a voluntarist solution, Sellafield was not assumed to be the de facto site under consideration, and so it was not the predetermined outcome resulting from some form of risk assessment, as it was in the 1990s. Under Nirex's analysis, Sellafield was judged to be the best site because of the costs and risks associated with waste transportation (Nirex, 2005a); yet this was 
a subjective judgement (based upon the weighting criteria applied to transportation costs and risks) and hence the outcome of Nirex's decision analysis lacked legitimacy (Stirling, 1996). As the voluntarist siting followed a more transparent (and more environmentally just) options-assessment process based upon evaluation of underlying public perceptions, ethical concerns and non-technical criteria, the risk distribution dimension had much greater flexibility and stronger local democratic control. This latter factor reveals the procedural and recognition justice aspects that made the MRWS process a success from an environmental justice standpoint.

In practice, three local authorities came forward in 2009 as part of the EOI stage: Cumbria County Council, and the District Councils of Allerdale and Copeland. They collectively formed the West Cumbria Managing Radioactive Waste Partnership (hereafter "The Partnership"), in conjunction with local business interests, churches, voluntary organisations, trades unions and environmental/conservation organisations. The Partnership ran a comprehensive public and stakeholder engagement programme within affected communities across the region, including a local media strategy, town hall meetings and school projects, workshops, leaflet campaigns, and a range of phone, and internet consultation approaches for canvassing input. This was combined with technical assessment of geological data in the region, which too was deliberated upon with local stakeholders, and research into the "net support" for continued involvement in a GDF and the impact of the decision to participate on the brand value of the Cumbrian region (Ipsos MORI, 2013) to generate a comprehensive analytic-deliberative process for decision-making. The final report in August 2012 (West Cumbria Managing Radioactive Waste Safely Partnership, 2012) was comprehensive and influential upon the councils' vote on whether it was going to proceed to the next stage and enter into the DTP process.

What differed in the Partnership-led process, when compared to Nirex's siting activities in the 1980s and 1990s, was a greater degree of recognition-based justice for West Cumbrian identity as an historically nuclear community bordered by more affluent tourism-heavy regions (specifically the Lake District National Park), and greater devolved power within the decision-making process. The Partnership was both an evidence gathering and decision-support body, which had political leverage with nuclear industry and Government authorities (including the Nuclear Decommissioning Authority's Radioactive Waste Management Directorate, Nirex's successor) than in the previous site selection process for an RCF. As the voluntarism aspect also included a package of direct funding for local engagement activities, the decision was more procedurally just, as it provided not only the opportunity to engage broadly on issues such as risk acceptability, community compensation and local environmental impacts (giving devolved powers to local authorities on the decision) but also the resources and capacity to engage (and thus meeting the requirements for due process in decision-making — one of the principles of Prima Facie Political Equality mentioned above: Shrader-Frechette, 2002). 


\section{Radioactive Waste Management and Major Infrastructure Planning}

The MRWS process had clear institutional safeguards to ensure greater environmental justice, particularly when compared to previous siting processes, and myriad other major infrastructure and pollution management processes in UK policy and planning. Specifically, with regard to distributive justice, there are two elements. First, the safe onsite storage of waste as an interim measure received greater recognition (that shorter-term environmental safety of residents in Whitehaven and the other population centres surrounding Sellafield received greater recognition and priority). Second, by adopting a voluntarist model, Sellafield was not assumed to be the de facto site under consideration and so risk distribution was not a predetermined outcome of an inflexible technology decision based upon technical criteria (Cotton, 2017b).

Yet in practice, despite this, the voluntarist approach was also a failure in national policy terms. After a period of internal political deliberation, the councils each made individual decisions on whether to proceed to the DTP in January 2013. What was controversial was that the two District Councils (Allerdale and Copeland) voted in favour of moving to the siting stage, whilst Cumbria County Council (the tier above) voted to withdraw. In part this was due to concerns over the broader impacts to the Cumbrian region, primarily as a matter of recognition-related justice. As Bill Jefferson, chairman of the Lake District National Park Authority, stated in a letter to the Department of Energy and Climate Change:

While we do not know what precise impacts a repository under the national park would have on its special qualities, I am concerned such a proposal could adversely affect the Lake District's national and inter-national standing, reputation and integrity, prejudicing the delivery of the authority's vision to the detriment of the Cumbrian tourism economy.

Moving to the DTP stage required the agreement amongst the three parties-the councils had a Memorandum of Understanding that bound them to share in a joint decision, and without that consensus all three parties were forced to reject the recommendations. This brought the volunteer process to a close, and there have since been no other volunteers, leading to the hiatus of the voluntarist process (as no new communities were coming forward) and a further reformulation of radioactive waste policy strategy within Government (Blowers, 2014)—and this remains an ongoing process at the time of writing.

\section{Streamlining Radioactive Waste Management Policy}

In 2014, the Conservative and Liberal Democrat Coalition Government published a White Paper, following a consultation review (Department of Energy and Climate Change, 2014). In the White Paper, policy was reformulated to integrate the MRWS process into broader planning legislation for major infrastructure projects, namely The Planning Act 2008 and the Localism Act 2011. Under this legislation, major infrastructure projects such as power stations, electricity and gas transmission 
systems, motorways, airports are designated under a National Policy Statement (NPS), and then individual developers apply for planning consent to the Secretary of State. This is how marketised infrastructure projects are planned for in the UK, and this is significant for the concept of scalar environmental justice.

Since the 1990s in countries across Europe (but specifically the UK in this context), there has been a considerable shift in the ways in which infrastructure is planned for and governed. There has been a significant shift towards the regulatory state (as characterised by processes of privatisation and deregulation) and away from the "dirigiste state" of the past (whereby the state exerts a strong directive influence over investment). Thus, regulation rather than public ownership, planning or centralised administration has become the key context in which large-scale infrastructures have come to be governed (Majone, 1994). This means that a strategic approach to the organisation of space at different levels of scale has become the norm (Albrechts, 2004), and hence a renewed emphasis upon spatial planning as a political process. This means that projects like radioactive waste management have become new spaces of governance (see, for example, Allmendinger \& Haughton, 2010), promoting new ways of thinking about space and place, and the role of spatial and scalar strategies in contemporary governance contexts (see also Healey, 2004). In the UK, this new space of governance is the Major Infrastructure and Environment Unit (MIEU) within the Planning Inspectorate (itself within central government). The MIEU ensures that community consultation is undertaken by the developer before planning consent is given (alongside environmental protection mechanisms such as environmental impact assessment if appropriate). However, ultimately the Secretary of State makes the decision, which the Conservative Government claims ensures democratic legitimacy through elected representation.

Scalar relations within this new space of governance are important. This is because different categories of scale are defined within policy and then reified within planning practice; enacting a type of political separation between the predefined scalar boundaries. Social actors then try to challenge or reinterpret these scales in order to further their own strategic agendas (Johnstone, 2014). I understand the political strategies of "scaling" decisions with reference to Cox's (1998a, 1998b) work. Cox examines scale as a series of spaces of engagement grounded in networks of interaction. This is contrasted with spaces of dependence-broadly fixed, localised and geographically situated arenas within which individuals become embedded in socio-economic and/or (in this case) environmental interests. Spaces of engagement are sets of relations that extend into and beyond spaces of dependence as a means to construct relations: networks of association, exchange and politics within "broad fields of events and forces" (Cox, 1998b) that are relational and contingent upon the particular networks and associations in any given instance (see also Jones, 1998). Cox describes a process of how actors can "jump scales" (see also Swyngedouw, 2010), for example, how local communities seek to shift political dialogue away from a focus upon isolated site communities, property prices, community stigma and local economic development, towards national/international level policy-making issues of energy systems development and nuclear futures, coordinated national waste strategies and the institutional legitimacy of radioactive waste management organisations (in this case). Likewise, technical and political organisations 
that seek to streamline planning decisions will commonly seek to minimise political support for local social movements of opposition by rescaling the decision downwards to local site support, using NIMBY labels, decide-announce-defend strategies of science communication and the isolation of local representatives within national policy-making. Thus, scales can be jumped upwards or downwards depending upon the actors' relevant positions within the space of engagement, the decision context and their capacity to shape the political discourse with subsequent effects upon justice outcomes.

The new spaces of planning governance in UK have rescaled decisions on infrastructure projects to the nation state scale, rather than the regional, local or community scale. Such legislation has removed the regional tiers of government and associated planning instruments (such as local planning inquiries). This reflects an underlying social philosophy of infrastructure as national interest (alternatively, the 'public good' Syme \& Nancarrow, 2001), whereby infrastructure is construed as a crucial element of economic growth and industrial development beyond the immediate economic benefits to developers or host communities. Democratic legitimacy in decision-making is derived from an aggregate or representative democratic model (i.e. from elected representatives) rather than a deliberative democratic model. However, this means that project developments frequently exacerbate environmental injustices to local communities as these groups effectively have no power to question the need case for the infrastructure (as this is designated by a National Policy Statement, and not at the point of development), holistically evaluate the project's feasibility, present alternative options or challenge the political power of central government (for example, Cotton, 2014; Cotton \& Devine-Wright, 2013), thus fundamentally violating the prima facie principle of political equality - that developers must prove the need for the infrastructure (not communities challenge a predefined decision), provide opportunities for informed consent, participation in decisions and compensation for losses and risks. The social construction of a locally situated infrastructure project as nationally significant circumvents local environmental justice with a utilitarian principle of the "greater good" by framing it at the nation scale. This framing of scale has been heavily criticised as exacerbating democratic deficits (Bickerstaff \& Johnstone, 2017; Johnstone, 2010, 2014), and hence the associated distributive, procedural and recognition injustices. As RWM procedures are becoming folded into this new regime, the potential rescaling of the decision from local partnership to national decision will cause new scalar environmental injustices to emerge.

\section{Scalar Parity and Environmental Justice}

I argue that the MRWS process was an innovation in planning governance that was successful in balancing multiple spaces of engagement in a way that has not been seen before or since in modern infrastructure policy. Thus, broader lessons can be drawn from this success. I suggest that the MRWS success could be framed in terms of the capacity for scalar parity created in the spaces of engagement between local 
communities, regional political authorities (councils) and national nuclear waste authorities (such as the Nuclear Decommissioning Authority Radioactive Waste Management Directorate NDARWMD and to an extent with BIS and DECC). I argue also that this model should be normatively implemented in other major infrastructure decision-making contexts.

I proffer the concept of scalar parity as, to borrow Webler's (1995) term, an "evaluative yardstick" for assessing the justice dimensions of environmental plans and projects-in essence a means to evaluate whether fairness is achieved within a decision-making process across multiple scales. The partnership approach employed in RWM decision-making allowed community input to RWM as a local-to-regionalfocused process of politics on what would otherwise be seen as a national policy issue. I suggest that this was possible because the space of engagement in RWM decision-making was "performed" simultaneously at both the local scale, within a local space of dependence (where the waste would ultimately be sited), at a regional scale where issues of Cumbrian brand identity and tourist success could be researched and debated, and at a national scale through the much larger space of dependence (ultimately to accept national wastes transported to the region from nuclear producing sites outside of Cumbria). The decision model had scalar parity because local authorities and associated community stakeholders within the Partnership adopted the role of a political fulcrum - they successfully balanced local, regional and national scales through their simultaneous involvement in these multiple spaces of engagement.

The conduit of local-to-regional-to-national encouraged affected community members to engage with issues of nuclear futures, waste transportation across the country and risk burden sharing between their community and nuclear sites in other regions-effectively "scaling-up" deliberation beyond the local concerns that are commonly defined (pejoratively) as not-in-my-back-yard (NIMBY) issues (DevineWrigh, 2010; Feldman \& Turner, 2010). I use the term conduit here to define a set of formal mechanisms through which communities and national authorities engaged simultaneously and (relatively) smoothly with minimal conflict. As a normative principle, I argue that under a model of scalar parity it is the moral responsibility of community members to "scale up" their deliberation honestly. This requires both a willingness and capacity to think in strategic terms about the problem under consideration at multiple scales. This can only be achieved through careful and competent facilitation, adequate resourcing of engagement practices and a shared agreement to "launder personal preferences" (Goodin, 1986) in favour of those that benefit the community, the region or the nation.

The MRWS process was successful in creating a Partnership fulcrum to this deliberative process of scaling-up, in the sense that it had the political capacity and trust from the community to balance local interests, encourage national-level thinking through its engagement activities and yet also have direct influence upon all the other actors at the higher-up scales. The responsibility of communities to scale up their deliberations is matched by a concomitant responsibility of technical authorities to firstly identify the appropriate scale of engagement for the issue under consideration (to find the appropriate fulcrum point for any plan put forward), and secondly to facilitate the process by which locally affected actors can scale up their 
deliberations to regional and national spaces of engagement. This facilitation should include resources for comprehensive, independently facilitated engagement to occur. The MRWS process succeeded in this regard because the Partnership was given the resources to actively create spaces of engagement and make them available for locally affected host communities through their research, canvassing of opinion and two-way deliberative dialogue processes. It is in this sense that I suggest the voluntarist and partnership model ensured scalar parity between local communities and national authorities, and in turn how environmental justice was achieved. I argue, on a broader level, that such Partnership and volunteerist approaches are necessary prerequisites to promote flexibility and local control in the scaling of spaces of engagement across multiple spaces of dependence in managing any complex and contentious environmental issue, and thus achieve prima facie political equality between local, regional and national-scale actors involved-where decisions are sufficiently justified as necessary and fair at multiple scales and where imbalances can be rectified through a fair negotiation process (particularly around compensation/community benefits packages) through the fulcrum of the partnership model.

In reality, however, by drawing the MRWS process back into the politically controversial system of national infrastructure planning legislation, the scales of political engagement with environmental justice change - taking powers away from local and regional authorities (such as the Partnership or local councils). The potential change to the decision-making system draws more power to central government under the rubric of nationally significant infrastructure planning, based upon a guiding principle of the national good (however, defined). This disturbs the scalar parity of local site community's engagement with national authorities. It creates opportunities for a rescaling of politics that allows central authorities to impose unwanted site selection, diminishing the capacity for communities to oppose unjust environmental decisions through dialogue and facilitated exchange within an appropriate space of engagement. This, in essence, generates risks of greater procedural environmental injustices as RWM planning reverts back to a decision-making model that more closely mirrors the failed top-down approaches of Nirex in previous decades.

This problem is significant not just for RWM, but for other infrastructure projects as well. Lessons in that regard can be drawn from new-build nuclear policy in the UK, which emerged at the same time as the MRWS process but followed a far less environmentally just decision process. The UK's policy on new nuclear build under the so-called nuclear renaissance (Nuttall, 2004) involves Government aims to have 16 GWe of new nuclear capacity operating by 2030, with no restriction on foreign equity. The key governmental priority has been to ensure the successful so-called generation three programme of nuclear reactors to be built over the two decades up to 2030 (DECC, 2013), and there is no direct input from citizens upon the broader energy policy strategy on which this decision is based. In 2011 a deal was tabled with France's EDF Energy to build two Areva-designed European Pressurised Reactor (EPRs) at Hinkley Point and Somerset, and two at Sizewell and Suffolk with a total financing cost of $£ 24.5$ billion (Černoch \& Zapletalová, 2015). EDF Energy also proposed to work with a foreign investment partner China General Nuclear Power Corporation (CGN) to deploy the Chinese Hualong HPR-1000 reactor at Bradwell, Essex. The Hinkley Point C Nuclear Plant (HPCNPP) is a $3200 \mathrm{MWe}$ 
reactor which will be constructed adjacent to the existing site. Since being granted development consent, the HPCNPP has become a key component of political debate over renewed nuclear power in the UK-specifically the relationship between planning, policy-making and environmental justice.

That the HPCNPP was licensed so quickly when compared to the protracted (and unsuccessful) RWM solution in West Cumbria is testament to UK energy policy developments since the 2008 Energy Act under the former Labour Government, and pressure towards ever streamlined planning solutions for nuclear power. The Energy Act 2008 introduced strategic siting assessment and strategic environmental assessment processes to identify and assess suitable sites for new nuclear plants. Then, as Johnstone (2014) argues the planning reforms of the Planning Act 2008 and the former Coalition Government's Localism Act 2011 reduced the range of political opportunities for actors at different scales to have a say over the nuclear policy-making process. These policies were intended as a means to further reduce delays from proposal to plant construction. This has resulted in a lack of transparency in decision-making over nuclear policy development (Jenkins, McCauley, \& Warren, 2017), raising issues of procedural and recognition justice for local communities and taxpayers. Johnstone (2014) specifically raises concerns that such reforms make nuclear power decisions unjust as they are fundamentally post-political - the methods of democratic decision-making used in spatial planning do not lead to community empowerment but rather to the rubber-stamping of the interests of private developers-issues seen in other major infrastructure projects such as energy from waste facilities (Cotton, 2014), gas pipelines (Groves, 2015) and shale gas exploration sites (Whitton et al., 2017). In each case there has been a shift towards what Chilvers (2010) terms uninvited forms of engagement: specifically pushing citizens into direct action and vocal social movements of opposition as their political power in formal, invited spaces of engagement diminishes, and we will see more of this occurring as the scalar disparity of planning is applied across all infrastructure sectors.

\section{Conclusions}

There is an important policy-learning process to be gained from the MRWS programme. Unlike nuclear new-build and other forms of nationally significant infrastructure projects such as shale gas or electricity transmission systems, the MRWS programme had clear environmental justice consideration built into the fabric of the policy. By making an overt commitment to dialogue through partnership, through the exploration of bottom-up community perspectives through a well-funded engagement process and by providing (potentially) long-lasting community benefits, the MRWS process became an exemplar of environmental justice resolution in major infrastructure planning. I suggest that the key to this success is the in-built capacity to simultaneously scale up local community concerns, and scale down national concerns within a voluntary-participatory decision-making process, to a level whereby both can be effectively balanced such that meaningful, low-conflict political dialogue can occur - to create what Gregson (2012) refers to as a "cold politics" of 
radioactive waste. If this process is abandoned for RWM or ignored in other infrastructure development fields, then affected communities will become increasingly united by a sense of common threat, spatially coordinated across the affected spaces of dependence (for example, when nuclear new-build sites are selected because they are close to existing/decommissioned facilities, or if RWM facilities are chosen in locations near Sellafield again by a top-down government-led process). By doing so, Government policy will only reinforce environmental injustice and exacerbate social opposition to these "wicked" infrastructure policy problems with the attendant effects on policy failure and public mistrust. Moreover, as we see a broader move within infrastructure planning processes towards this model of "streamlining" decisions through rescaling to top-down centralised government control, this injustice will grow across a range of infrastructures sectors (where nuclear newly build is just one example). Only by rebalancing local, regional and national scales of interest through a partnership model that can create sufficient parity between the competing scales of engagement can such environmental injustices be ameliorated or resolved.

Acknowledgements This work was supported by the History of Nuclear Energy and Society project and funded by the Euratom research and training programme 2014-2018 under Grant Agreement No. 662268.

Funding This study was funded by the Horizon 2020 Euratom NRFP, Grant No. 662268.

\section{Compliance with Ethical Standards}

Conflict of interest The author declares that they have no conflict of interest.

Human and Animal Rights This article does not contain any studies with human participants performed by any of the authors.

Open Access This article is distributed under the terms of the Creative Commons Attribution 4.0 International License (http://creativecommons.org/licenses/by/4.0/), which permits unrestricted use, distribution, and reproduction in any medium, provided you give appropriate credit to the original author(s) and the source, provide a link to the Creative Commons license, and indicate if changes were made.

\section{References}

Agyeman, J. (2002). Constructing environmental (in)justice: Transatlantic tales. Environmental Politics, $11(3), 31-53$.

Agyeman, J. (Ed.). (2003). Just Sustainabilities: Development in an Unequal World. Cambridge: MIT Press.

Agyeman, J., \& Evans, B. (2004). Just sustainability: The emerging discourse of environmental justice in Britain? The Geographical Journal, 170(2), 155-164.

Albrechts, L. (2004). Strategic (spatial) planning reexamined. Environment and Planning B: Planning and Design, 31(5), 743-758.

Allmendinger, P., \& Haughton, G. (2010). Spatial planning, devolution, and new planning spaces. Environment and Planning C: Government and Policy, 28(5), 803-818.

Appeal Decision Letter, 17 Mar. 1997, para. 9.

Atherton, E., \& Poole, M. (2001). The problem of the UK's radioactive waste: What have we learnt? Interdisciplinary Science Reviews, 26(4), 296-302. 
Barnes, M., Newman, J., \& Sullivan, H. (2004). Power, participation, and political renewal: Theoretical perspectives on public participation under New Labour in Britain. Social Politics: International Studies in Gender, State \& Society, 11(2), 267-279.

Bell, D., Gray, T., Haggett, C., \& Swaffield, J. (2013). Re-visiting the 'social gap': Public opinion and relations of power in the local politics of wind energy. Environmental Politics, 22(1), 115-135.

Bergmans, A., Sundqvist, G., Kos, D., \& Simmons, P. (2015). The participatory turn in radioactive waste management: Deliberation and the social-technical divide. Journal of Risk Research, 18(3), 347-363.

Berkhout, F. (1991). Radioactive Waste: Politics and Technology. Abingdon: Routledge.

Bickerstaff, K., \& Agyeman, J. (2009). Assembling justice spaces: The scalar politics of environmental justice in North-East England. Antipode, 41(4), 781-806.

Bickerstaff, K., \& Johnstone, P. (2017). The re-scaling of energy politics. In The Routledge Research Companion to Energy Geographies, edited by M. J. Pasqualetti, S. Bouzarovski, \& V. Castán Broto, 139-152. Abingdon: Routeledge Earthscan.

Blowers, A. (1999). Nuclear waste and landscapes of risk. Landscape Research, 24(3), 241-263.

Blowers, A. (Ed.). (2006). Ethics and Decision Making for Radioactive Waste. London: Committee on Radioactive Waste Management.

Blowers, A. (2010). Why dump on us? Power, pragmatism and the periphery in the siting of new nuclear reactors in the UK. Journal of Integrative Environmental Sciences, 7(3), 157-173.

Blowers, A. (2014). A geological disposal facility for nuclear waste: If not Sellafield, then where? Town and Country Planning, 83(12), 545-553.

Blowers, A. (2016). The Legacy of Nuclear Power. Abingdon: Earthscan from Routledge.

Blowers, A., Lowry, D., \& Solomon, B. D. (1991). The International Politics of Nuclear Waste. London: MacMillan.

Blowers, A., \& Pepper, D. (1988). The politics of nuclear power and radioactive waste disposal: From state coercion to procedural justice? Political Geography Quarterly, 7(3), 291-298.

Blowers, A., \& Sundqvist, G. (2010). Radioactive waste management: Technocratic dominance in an age of participation. Journal of Integrative Environmental Sciences, 7(3), 149-155.

Bullard, R. D. (1989). Race and the Siting of Hazardous Waste Sites. Berkeley: University of California Press.

Bullard, R. D. (Ed.). (1993). Confronting Environmental Racism: Voices from the Grassroots. Boston: South End Press.

Bullard, R. D. (2000). Dumping in Dixie: Race, Class and Environmental Quality. Colorado: Westview Press.

Castán Broto, V., Burningham, K., Carter, C., \& Elghali, L. (2010). Stigma and attachment: Performance of identity in an environmentally degraded place. Society and Natural Resources, 23(10), 952-968. https://doi.org/10.1080/08941920802705776.

Černoch, Filip., \& Zapletalová, Veronika. (2015). Hinkley point C: A new chance for nuclear power plant construction in central Europe? Energy Policy, 83, 165-168.

Chilvers, J. (2010). Sustainable participation? Mapping out and reflecting on the field of public dialogue on science and technology. Harwell: Sciencewise Expert Resource Centre.

Ciplet, D., Roberts, J. T., \& Khan, M. (2013). The politics of international climate adaptation funding: Justice and divisions in the greenhouse. Global Environmental Politics, 13(1), 49-68.

Clayton, S., Koehn, A., \& Grover, E. (2013). Making sense of the senseless: Identity, justice, and the framing of environmental crises. Social Justice Research, 26(3), 301-319.

Cole, L., \& Foster, S. (2001). From the Ground Up: Environmental Racism and the Rise of the Environmental Justice Movement. New York: New York University Press.

Collier, D. (2005). CoRWM PSE1 Evaluation V4. Oxford: Faulkland Associates.

CoRWM. (2004). Guiding principles. In Committee on Radioactive Waste Management. Accessed 11 Nov. 2006.

CoRWM. (2006a). Managing our Radioactive Waste Safely: CoRWM's Recommendations to Government. London: Committee on Radioactive Waste Management.

CoRWM. (2006b). Programme of work. In Commitee on Radioactive Waste Management. http://www. corwm.org.uk/content-591. Accessed 2 Mar 2017.

CoRWM. (2007). Moving forward. In CoRWM's Proposals for Implementation. London: Commitee on Radioactive Waste Management. 
CoRWM. (2011). Position paper on public and stakeholder engagement. In CoRWM Doc. 2850 Draft 12 (1 February 2011). edited by L. Netherton. London: Committee on Radioactive Waste Management.

Cotton, M. (2009). Ethical assessment in radioactive waste management: A proposed reflective equilibrium-based deliberative approach. Journal of Risk Research, 12(5), 603-618.

Cotton, M. (2014). Environmental justice challenges in United Kingdom infrastructure planning: Lessons from a welsh incinerator project. Environmental Justice, 7(2), 39-44.

Cotton, M. (2017a). Fair fracking? Ethics and environmental justice in United Kingdom shale gas policy and planning. Local Environment, 22(2), 185-202.

Cotton, M. (2017b). Nuclear Waste Politics: An Incrementalist Perspective. Abingdon: Routledge.

Cotton, M., \& Devine-Wright, P. (2013). Putting pylons into place: A UK case study of public beliefs about the impacts of high voltage overhead transmission lines. Journal of Environmental Planning and Management, 56(8), 1225-1245.

Cox, K. R. (1998a). Representation and power in the politics of scale. Political Geography, 17(1), 41-44.

Cox, K. R. (1998b). Spaces of dependence, spaces of engagement and the politics of scale, or: Looking for local politics. Political Geography, 17(1), 1-23.

Cumbria Intelligence Observatory. (2015). District Deprivation Summary Copeland 2015. Cumbria County Council.

Cutter, S. L. (1995). Race, class and environmental justice. Progress in Human Geography, 19(1), $111-122$.

DECC. (2013). Long-term Nuclear Energy Strategy. London: Department of Energy and Climate Change.

DEFRA. (2001). Managing Radioactive Waste Safely: Proposals for Developing a Policy for Managing Solid Radioactive Waste in the UK. London: Department for Environment Food and Rural Affairs.

Department of Energy and Climate Change. (2014). Implementing Geological Disposal: A Framework for the Long-term Management of Higher Activity Radioactive Waste. London: Department of Energy and Climate Change.

DETR. (1999). A Better Quality of Life: A Strategy for Sustainable Development in the United Kingdom. London: Department of the Environment, Transport and the Regions.

Devine-Wright, P. (2010). Public engagement with large-scale renewable energy technologies: Breaking the cycle of NIMBYism. WIREs Climate Change, 2(1), 19-26. https://doi.org/10.1002/wcc.89.

Dobson, A. (1998). Justice and the Environment: Conceptions of Environmental Sustainability and Dimensions of Social Justice. Oxford: Oxford University Press.

Durant, D. (2007). Burying globally, acting locally: Control and co-option in nuclear waste management. Science and Public Policy, 34(7), 515-528.

Faber, D., \& McCarthy, D. (2001). The evolving structure of the environmental justice movement in the United States: New models for democratic decision-making. Social Justice Research, 14(4), $405-421$.

Feldman, S., \& Turner, D. (2010). Why not NIMBY? Ethics, Policy and Environment, 10, 251-266.

Foster, S. (1993). Race(ial) matters: The quest for environmental justice. Ecological Law Quarterly, 20(4), 721-753.

Goodin, R. E. (1986). Laundering preferences. In J. Elster \& A. Hylland (Eds.), Foundations of Social Choice Theory. Cambridge: Cambridge University Press.

GreenPeace. (2005). How Did the Secret Nirex List of Potential Nuclear Waste Dump Sites Come About? London: GreenPeace.

Gregory, S., \& Satterfield, T. (2002). Beyond perception: The experience of risk and stigma in community contexts. Risk Analysis, 22(2), 347-358.

Gregson, Nicky. (2012). Projected futures: The political matter of UK higher activity radioactive waste. Environment and Planning A, 44(8), 2006-2022.

Groves, C. (2015). The bomb in my backyard, the serpent in my house: Environmental justice, risk, and the colonisation of attachment. Environmental Politics, 24(6), 853-873.

Hall, T. (1986). Nuclear Politics: The History of Nuclear Power in Britain. London: Penguin.

Hall, S. (2013). Energy justice and ethical consumption: Comparison, synthesis and lesson drawing. Local Environment, 18(4), 422-437.

Hastings, J. J., Rhodes, D., Fellerman, A. S., McKendrick, D., \& Dixon, C. (2007). New approaches for sludge management in the nuclear industry. Powder Technology, 174(1-2), 18-24.

Healey, P. (2004). The treatment of space and place in the new strategic spatial planning in Europe. International Journal of Urban and Regional Research, 28(1), 45-67. 
Hernández, D. (2015). Sacrifice along the energy continuum: A call for energy justice. Environmental Justice, 8(4), 151-156.

Hofrichter, R. (Ed.). (1993). Toxic Struggles: The Theory and Practice of Environmental Justice. Philadelphia: New Society.

Holliday, F. G. T. (2005). The dumping of radioactive waste in the deep ocean: Scientific advice and ideological persuasion. In D. E. Cooper \& J. A. Palmer (Eds.), The Environment in Questions (pp. 51-64). London: Routledge.

Houston, D. (2013). Environmental justice storytelling: Angels and isotopes at Yucca Mountain, Nevada. Antipode, 45(2), 417-435.

Hunt, J. (2004). Review of intensive PSE methods. CoRWM.

Ipsos MORI. (2013). Baseline perceptions of Cumbria, the Lake District and its brands. In Research Report on Qualitative and Quantitative Work Conducted by Ipsos MORI on Behalf of the Cumbria Brand Management Group. London: Ipsos MORI.

Jenkins, Kirsten., McCauley, Darren., \& Warren, Charles. R. (2017). Attributing responsibility for energy justice: A case study of the hinkley point nuclear complex. Energy Policy, 108, 836-843.

Jessup, B. (2014). Environmental justice as spatial and scalar justice: A regional waste facility or a local rubbish dump out of place? McGill International Journal of Sustainable Development Law and Policy, 9(2), 71-107.

Johnstone, P. (2010). The nuclear power renaissance in the UK: Democratic deficiencies within the "consensus' on sustainability. Human Geography, 3(2), 91-104.

Johnstone, P. (2014). Planning reform, rescaling, and the construction of the postpolitical: the case of the planning Act 2008 and nuclear power consultation in the UK. Environment and Planning C: Government and Policy, 32(4), 697-713.

Jonas, A. E. G. (2006). Pro scale: Further reflections on the 'scale debate'in human geography. Transactions of the Institute of British Geographers, 31(3), 399-406.

Jones, K. T. (1998). Scale as epistemology. Political Geography, 17(1), 25-28.

Kaswan, Alice. (2002). Distributive justice and the environment. NCL Review, 81, 1031.

Kelling, G., \& Knill, J. (1997). The nirex story: A geological perspective. Geoscientist, 7, 10-13.

Kemp, R. (1992). The Politics of Radioactive Waste Disposal. Manchester: Manchester University Press.

Kershaw, P. J., Leonard, K. S., McCubbin, D., \& Aldridge, J. N. (2001). Plutonium: The legacy of sellafield. Radioactivity in the Environment, 1, 305-328.

Knudsen, J. K., Wold, L. C., Aas, Ø., Haug, J. J. K., Batel, S., Devine-Wright, P., et al. (2015). Local perceptions of opportunities for engagement and procedural justice in electricity transmission grid projects in Norway and the UK. Land Use Policy, 48, 299-308.

Krütli, Pius., Stauffacher, Michael., Pedolin, Dario., Moser, Corinne., \& Scholz, Roland. W. (2012). The process matters: Fairness in repository siting for nuclear waste. Social Justice Research, 25(1), $79-101$.

Kurtz, H. E. (2003). Scale frames and counter-scale frames: Constructing the problem of environmental injustice. Political Geography, 22(8), 887-916.

Kurtz, H. E. (2008). The politics of environmental justice as the politics of scale: St. James Parish, Louisiana, and the Shintech Siting Controversy. In A. Herod \& M. W. Wright (Eds.), Geographies of Power (pp. 249-273). London: Blackwell Publishers Ltd.

Kyne, D., \& Bolin, B. (2016). Emerging environmental justice issues in nuclear power and radioactive contamination. International Journal of Environmental Research and Public Health, 13(7), 700.

Lawless, W. F., Whitton, J., \& Poppeliers, C. (2008). Case studies from the United Kingdom and the United States of stakeholder decision making on radioactive waste management. Practice Periodical of Hazardous, Toxic, and Radioactive Waste Management, 12(2), 70-78.

Lawrence, R. L., Daniels, S. E., \& Stankey, G. H. (1997). Procedural justice and public involvement in natural resource decision making. Society and Natural Resources, 10(6), 577-589.

Levine, A. G. (1982). Love Canal: Science, Politics, and People. Lexington: Lexington Books.

Low, N., \& Gleeson, B. (1998). Justice, Society and Nature: An Exploration of Political Ecology. London: Routledge.

Mackerron, G. (2015). Multiple challenges: Nuclear waste governance in the United Kingdom. In A. Brunnengräber, M. R. Di Nucci, A. M. I. Losada, L. Mez, \& M. A. Schreurs (Eds.), Nuclear Waste Governance: An International Comparison. Wiesbaden: Springer.

Mackerron, G., \& Berkhout, F. (2009). Learning to listen: institutional change and legitimation in UK radioactive waste policy. Journal of Risk Research, 12(7-8), 989-1008.

Majone, G. (1994). The rise of the regulatory state in Europe. West European Politics, 17(3), 77-101. 
Malone, C. R. (1991). High-level nuclear waste disposal: A perspective on technocracy and democracy. Growth and Change, 22(2), 69-74.

Marston, S. A. (2000). The social construction of scale. Progress in Human Geography, 24(2), $219-242$.

McCauley, Darren. A., Heffron, Raphael. J., Stephan, Hannes., \& Jenkins, Kirsten. (2013). Advancing energy justice: The triumvirate of tenets. International Energy Law Review, 32(3), 107-110.

McMillan, A. A., Heathcote, J. A., Klinck, B. A., Shepley, M. G., Jackson, C. P., \& Degnan, P. J. (2000). Hydrogeological characterization of the onshore quaternary sediments at Sellafield using the concept of domains. Quarterly Journal of Engineering Geology and Hydrogeology, 33(4), 301-323.

McSorley, J. (1990). Living in the Shadow: The Story of the People of Sellafield. London: Pan Books.

Newman, P. (2009). Markets, experts and depoliticizing decisions on major infrastructure. Urban Research and Practice, 2(2), 158-168.

Nirex. (2005a). Historic List of Possible Locations for a Radioactive Waste Repository, June 2005. Harwell: UK Nirex Ltd.

Nirex. (2005b). Review of 1987-1991 Site Selection for an ILW/LLW Repository. Harwell: United Kingdom Nirex Limited.

Nuttall, W. J. (2004). Nuclear Renaissance: Technologies and Policies for the Future of Nuclear Power. Boca Raton: CRC Press.

Parris, C. L., Hegtvedt, K. A., Watson, L. A., \& Johnson, C. (2014). Justice for all? Factors affecting perceptions of environmental and ecological injustice. Social Justice Research, 27(1), 67-98.

Pidd, H. (2016). Copeland byelection: We are a community of two halves. The Guardian, 26th December 2016.

Royal Commission on Environmental Pollution. (1976). Nuclear Power and the Environment. London: Royal Commission on Environmental Pollution.

Schlosberg, D. (1999). Environmental Justice and the New Pluralism: The Challenge of Difference for Environmentalism. Oxford: Oxford University Press.

Schlosberg, D. (2003). The justice of environmental justice: reconciling equity, recognition, and participation in a political movement. In A. Light \& A. de Shalit (Eds.), Moral and Political Reasoning in Environmental Practice (pp. 77-106). Cambridge: MIT Press.

Schlosberg, D. (2007). Defining Environmental Justice: Theories, Movements, and Nature. Oxford: Oxford University Press.

Senecah, S. L. (2004). The trinity of voice: The role of practical theory in planning and evaluating the effectiveness of participatory processes. In S. P. Depoe, J. W. Delicath, \& M.-F. A. Elsenbeer (Eds.), Communication and Public Participation in Environmental Decision Making (pp. 13-34). Albany: SUNY Press.

Shrader-Frechette, K. S. (2002). Environmental Justice: Creating Equality, Reclaiming Democracy. Oxford: Oxford University Press.

Simcock, Neil. (2014). Exploring how stakeholders in two community wind projects use a "those affected" principle to evaluate the fairness of each project's spatial boundary. Local Environment, 19(3), 241-258.

Simmons, P., \& Bickerstaff, K. (2006). The participatory turn in UK radioactive waste management policy. In Proceedings of VALDOR-2006. Stockholm, edited by K. Andersson (pp. 529-536). Sweden: Congrex.

Sovacool, B. K., \& Dworkin, M. H. (2015). Energy justice: Conceptual insights and practical applications. Applied Energy, 142, 435-444.

Stirling, A. (1996). On the Nirex MADA [Multi-Attribute Decision Analysis] Proof of evidence. In R. S. Haszeldine \& D. K. Smythe (Eds.), Radioactive waste disposal at Sellafield, UK: site selection, geological and engineering problems. Glasgow: University of Glasgow.

Swyngedouw, E. (2010). Place, Nature and the Question of Scale: Interrogating the Production of Nature. Berlin: Berlin-Brandenburgische Akademie der Wissenschaften.

Syme, G. J., \& Nancarrow, B. E. (2001). Social justice and environmental management: An introduction. Social Justice Research, 14(4), 343-347.

Towers, G. (2000). Applying the political geography of scale: Grassroots strategies and environmental justice. Professional Geographer, 52(1), 23-36.

Upreti, B. R., \& van der Horst, D. (2004). National renewable energy policy and local opposition in the UK: The failed development of a biomass electricity plan. Biomass and Bioenergy, 26(1), 61-69.

Walker, G. (2009). Beyond distribution and proximity: Exploring the multiple spatialities of environmental justice. Antipode, 41(4), 614-636. 
Walker, Gordon. P., \& Bulkeley, Harriet. (2006). Geographies of environmental justice. Geoforum, 37(5), 655-659.

Walker, G., Mitchell, G., Fairburn, J., \& Smith, G. (2005). Industrial pollution and social deprivation: Evidence and complexity in evaluating and responding to environmental inequality. Local Environment, 10(4), 361-377.

Watson, Matt., \& Bulkeley, Harriet. (2005). Just waste? Municipal waste management and the politics of environmental justice. Local Environment, 10(4), 411-426.

Webler, T. (1995). Right discourse in citizen participation: An evaluative yardstick. In O. Renn, T. Webler, \& P. Wiedemann (Eds.), Fairness and Competence in Citizen Participation. Dordrecht: Kluwer.

West Cumbria Managing Radioactive Waste Safely Partnership. (2012) The Final Report of the West Cumbria Managing Radioactive Waste Safely Partnership. Whitehaven: Copeland Borough Council.

Whitton, John., Brasier, Kathryn., Parry, Ioan. Mihangel., \& Cotton, Matthew. (2017). Shale gas governance in the United Kingdom and the United States: Opportunities for public participation and the implications for social justice. Energy Research and Social Science, 26, 11-22.

Whitton, John., Parry, Ioan. Mihangel., Akiyoshi, Mito., \& Lawless, William. (2015). Conceptualizing a social sustainability framework for energy infrastructure decisions. Energy Research and Social Science, 8, 127-138.

Wynne, B. (1993). Public Perceptions and the Nuclear Industry in West Cumbria. Lancaster: Lancaster University. 